\title{
Fetal activity and fetal wellbeing: an evaluation
}

\author{
JAMES F PEARSON, JUDITH B WEAVER
}

British Medical fournal, 1976, 1, 1305-1307

\section{Summary}

The clinical value of the 12-hour daily fetal movement count (DFMC) as a test of antepartum fetal wellbeing was assessed. The lowest $2.5 \%$ of 1654 DFMCs recorded by 61 women who subsequently delivered healthy infants fell below 10 movements per 12 hours. This level was taken as the lower limit of normal for clinical purposes. A normal DFMC in a population at risk was associated with a satisfactory fetal outcome. A low DFMC was associated with a high incidence of fetal asphyxia, and when fetal death occurred fetal movements rapidly diminished and stopped 12 to 48 hours before death. The DFMC is a generally applicable method of monitoring fetal welfare during pregnancy which provides an inexpensive adjunct or even an alternative to the more expensive placental function tests in current use.

\section{Introduction}

The relation between diminished fetal activity and fetal asphyxia is the subject of increasing investigation. Sadovsky and Yaffe ${ }^{1}$ observed in two patients that before intrauterine fetal death fetal movements decreased or stopped before the heart stopped. Mathews $^{2}$ suggested that a history of reduced fetal activity indicated serious fetal danger. Reinold, ${ }^{3}$ using ultrasound to record fetal activity, found that in cases of disturbed fetal welfare spontaneous movements were absent, infrequent, or sluggish. Maternal observations are subjective, with all the disadvantages that this implies, but about $87 \%$ of fetal movements recorded on an electromagnetic device were felt by the mother. ${ }^{4}$

We attempted to assess the clinical value of the daily fetal movement count (DFMC) using objective criteria. The study was conducted in three parts: (a) we established a normal range of fetal activity; $(b)$ we determined the DFMC in pregnancies at risk; and $(c)$ we determined the relation between DFMC and antepartum intrauterine death of the fetus.

\section{Methods}

ESTABLISHMENT OF NORMAL RANGE OF FETAL ACTIVITY

Pregnant women in whom there was no reason to suspect impaired placental perfusion were studied as outpatients. Each patient recorded the number of fetal movements occurring daily between $9.00 \mathrm{am}$ and $9.00 \mathrm{pm}$ from the $32 \mathrm{nd}$ week until delivery. The patients were instructed to decide for themselves what constituted a movement. Sixty-one patients subsequently delivered vigorous infants of above the 25 th percentile birth weight for gestational age, sex, and parity. ${ }^{5}$ These patients comprised the study group.

A total of 1654 DFMCs recorded by these 61 mothers were analysed (fig 1). The median value fell progressively from about 90 movements per 12 hours at the 32 nd week of gestation to 50 per 12 hours at the 40th week. About $2.5 \%$ of counts at each period of gestation fell below 10 per 12 hours. This level was used as the lower limit of normal for clinical purposes.

Department of Obstetrics and Gynaecology, Welsh National School of Medicine, University Hospital of Wales, Cardiff CF4 4XN JAMES F PEARSON, MD, MRCOG, senior lecturer JUDITH B WEAVER, FRCSED, MRCOG, lecturer

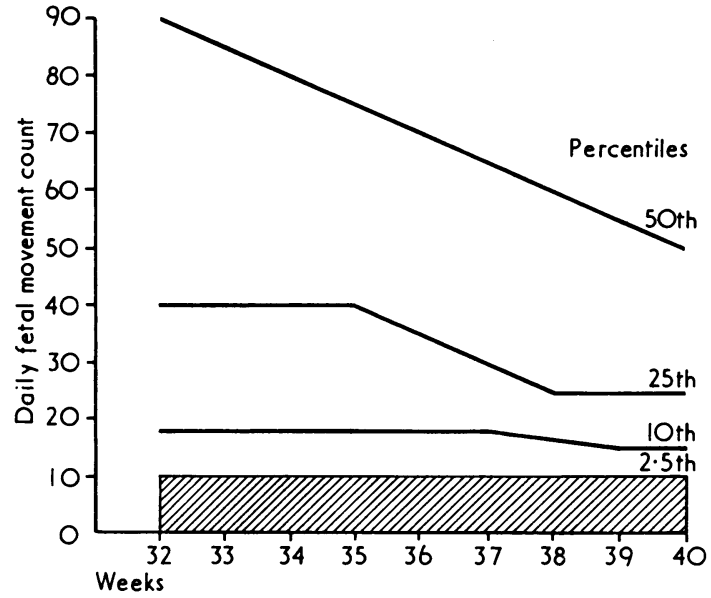

FIG 1-Percentile distribution of DFMCs below 50th percentile in 1654 counts from 61 patients between 32 and 40 weeks of pregnancy.

DFMC IN PREGNANCIES AT RISK

Most women who were antenatal inpatients between September 1973 and September 1975 recorded DFMCs. Altogether 122 of these patients $(a)$ had at least two 24-hour total urinary oestrogen estimations performed in the week before delivery; $(b)$ recorded DFMCs for at least seven days before delivery; and (c) underwent continuous fetal heart rate monitoring during labour. Maternal 24-hour total urinary oestrogen assay was the standard placental function test during this period; serial results of this test, together with clinical findings and biparietal cephalometry, primarily guided management.

The patients were divided into four groups. Group 1 consisted of 100 patients with normal DFMCs and normal 24-hour total urinary oestrogen excretion (less than $2 \mathrm{SDs}$ from the mean for gestational age). Group 2 included eight patients with normal DFMCs but low urinary oestrogen values on at least two successive occasions in the week before delivery. Group 3 included 10 patients with normal urinary oestrogen values but low DFMCs for at least one day before delivery. Group 4 consisted of four patients with low urinary oestrogen values in the week before delivery and low DFMCs for at least one day before delivery.

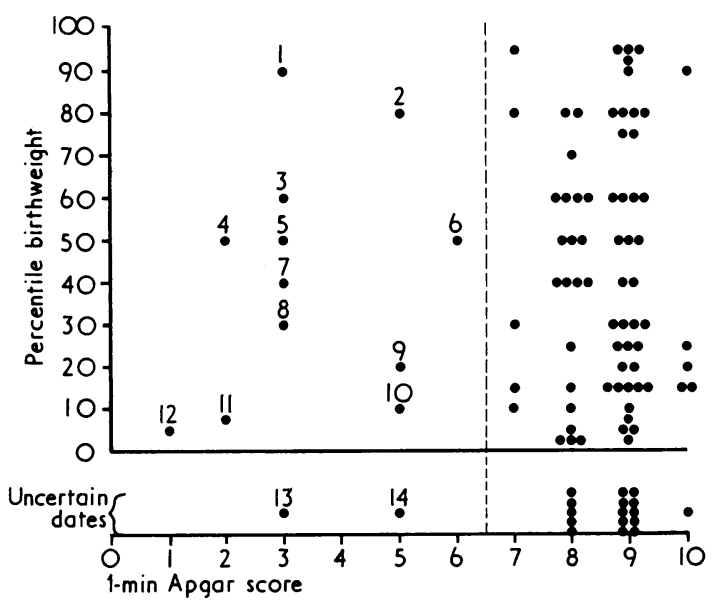

FIG 2-Percentile birthweight and 1-minute Apgar scores of infants of 100 patients with normal DFMCs and normal 24-hour total urinary oestrogen excretion. 


\section{Results}

Group 1-The infants were analysed according to the one-minute Apgar scores and percentile birth weight for gestational age, sex, and parity $^{5}$ (fig 2). Eighty-six had a one-minute Apgar score of 7 or more, and 14 scored 6 or less. The distribution of percentile birth weight was weighted towards the lower end of the percentile birth weight scale, as expected in a group at risk. The 14 infants scoring under 7 are detailed in table I. All these infants scored 10 at 10 minutes, but four required endotracheal intubation.

Group 2-Of these eight patients (see table II) five were submitted to elective caesarean section. Seven infants survived, and one died of respiratory distress due to prematurity. Labour was induced in cases 15,18 , and 22 , and emergency caesarean section was required in cases 15 and 18 for fetal distress with acidosis. Four of the seven infants of certain gestational age were below the 5 th percentile.

Group 3-Two infants, one with multiple abnormalities, died before labour (table II). Of the eight remaining patients, five required caesarean section for fetal distress, four with acidosis. Only one infant's birth weight was above the 15 th percentile.

Group 4-All four infants died (table II). The only infant born alive died of respiratory distress.

\section{DFMC AND ANTEPARTUM INTRAUTERINE FETAL DEATH}

Over the two-year period 11 infants died in utero of causes other than congenital abnormality. Details of four of these cases (cases 28, 33,34 , and 35) are given in table II; details of the remaining seven infants are shown in table III. Seven patients recorded DFMCs, and all showed a precipitate fall in the DFMC to levels below 10 per 12 hours before fetal death; movements thereafter stopped for 12 to 48 hours before the fetal heart stopped. DFMCs in four of these patients are shown in fig 3 . Serial oestrogen estimations were performed in five of the 11 patients in the week before delivery, and only one patient (case 28 ; table II) had normal values.

TABLE I-Details of delivery for those infants in group 1 (normal oestrogen values and normal movements) with Apgar scores of under 7 at one minute

\begin{tabular}{|c|c|c|c|c|c|c|}
\hline Case No & Pregnancy complication & Onset of labour & Mode of delivery & Indication & 1-min Apgar score & Additional factors \\
\hline $\begin{array}{l}1 \\
2 \\
3 \\
4\end{array}$ & $\begin{array}{l}\text { Diabetes } \\
\text { Unstable lie } \\
\text { Hypertension } \\
\text { Hypertension }\end{array}$ & $\begin{array}{l}\text { Induced } \\
\text { Spontaneous } \\
\text { Induced } \\
\text { Induced }\end{array}$ & $\begin{array}{l}\text { Caesarean section } \\
\text { Caesarean section } \\
\text { Forceps } \\
\text { Caesarean section }\end{array}$ & $\begin{array}{l}\text { Fetal distress } \\
\text { Prolapsed cord } \\
\text { Fetal distress } \\
\text { Fetal distress, }\end{array}$ & $\begin{array}{l}3 \\
5 \\
3 \\
2\end{array}$ & Tight nuchal cord \\
\hline 5 & Diabetes & & Elective caesarean & $\begin{array}{l}\text { Obstructed labour } \\
\text { Breech }\end{array}$ & 3 & \\
\hline 6 & Diabetes & & Elective caesarean & Previous caesarean & 6 & \\
\hline $\begin{array}{l}7 \\
8\end{array}$ & $\begin{array}{l}\text { Hypertension } \\
\text { Hypertension, } \\
\text { placenta praevia, }\end{array}$ & Induced & $\begin{array}{l}\text { section } \\
\text { Difficult forceps } \\
\text { Elective caesarean } \\
\text { section }\end{array}$ & $\begin{array}{l}\text { section } \\
\text { Fetal distress } \\
\text { Placenta praevia }\end{array}$ & $\begin{array}{l}3 \\
3\end{array}$ & \\
\hline 9 & Breech & Spontaneous & Breech with forceps & Breech & 5 & \\
\hline $\begin{array}{l}10 \\
11 \\
12 \\
13 \\
14\end{array}$ & $\begin{array}{l}\text { Small for dates } \\
\text { Placenta praevia } \\
\text { Hypertension } \\
\text { Polyhydramnios } \\
\text { Hypertension }\end{array}$ & $\begin{array}{l}\text { Induced } \\
\text { Induced } \\
\text { Induced } \\
\text { Induced }\end{array}$ & $\begin{array}{l}\text { Spontaneous } \\
\text { Caesarean section } \\
\text { Caesarean section } \\
\text { Caesarean section } \\
\text { Spontaneous }\end{array}$ & $\begin{array}{l}\text { Severe haemorrhage } \\
\text { Placental abruption } \\
\text { Failed trial of forceps }\end{array}$ & $\begin{array}{l}5 \\
2 \\
1 \\
5 \\
3\end{array}$ & Excessive sedation \\
\hline
\end{tabular}

TABLE II-Details of pregnancies and infants in groups 2,3 , and 4

\begin{tabular}{|c|c|c|c|c|c|c|c|}
\hline $\begin{array}{l}\text { Case } \\
\text { No }\end{array}$ & Pregnancy complication & $\begin{array}{l}\text { Maturity at } \\
\text { delivery } \\
\text { (weeks) }\end{array}$ & Type of delivery & Fetal acidosis $\dagger$ & $\begin{array}{l}\text { Apgar score } \\
\text { at } 1 \text { minute }\end{array}$ & $\begin{array}{l}\text { Percentile } \\
\text { birth weight }\end{array}$ & Outcome \\
\hline \multicolumn{8}{|c|}{ Group 2 (low oestrogen values; normal movements) } \\
\hline 15 & Hypertension & 38 & $\begin{array}{c}\text { Emergency caesarean } \\
\text { section }\end{array}$ & $+($ scalp $)$ & 3 & 40 th & Survived \\
\hline $\begin{array}{l}16 \\
17 \\
18\end{array}$ & $\begin{array}{l}\text { Unstable lie } \\
\text { Pre-eclamptic toxaemia } \\
\text { Small antepartum }\end{array}$ & $\begin{array}{r}35 \\
35 \\
\text { about } 38\end{array}$ & $\begin{array}{l}\text { section } \\
\text { Elective caesarean section } \\
\text { Elective caesarean section } \\
\text { Emergency caesarean } \\
\text { section }\end{array}$ & $\begin{array}{l}\text { ND } \\
\text { ND } \\
+(\text { scalp })\end{array}$ & $\begin{array}{r}8 \\
10 \\
6\end{array}$ & $\begin{array}{l}\text { 80th } \\
<5 \text { th }\end{array}$ & $\begin{array}{l}\text { Survived } \\
\text { Survived } \\
\text { Survived }\end{array}$ \\
\hline 19 & $\begin{array}{l}\text { haemorrhages } \\
\text { Severe pre-eclamptic }\end{array}$ & 36 & $\begin{array}{l}\text { section } \\
\text { Elective caesarean section }\end{array}$ & ND & 2 & $<5$ th & Survived \\
\hline 20 & $\begin{array}{l}\text { toxaemia } \\
\text { Small antepartum }\end{array}$ & 35 & Elective caesarean section & ND & 9 & 20th & Survived \\
\hline 21 & $\begin{array}{l}\text { haemorrhages } \\
\text { Small for dates, bad }\end{array}$ & 31 & Elective caesarean section & ND & 4 & $<5$ th & Neonatal death \\
\hline 22 & $\begin{array}{l}\text { Antepartum haemorrhage, } \\
\text { abruptio placentae, } \\
\text { small for dates }\end{array}$ & 34 & Forceps & ND & 3 & $<5$ th & Survived \\
\hline \multicolumn{8}{|c|}{ Group 3 (normal oestrogen values; few movements) } \\
\hline 23 & Threatened premature & 37 & Forceps & $(\mathbf{U A})+$ & 8 & 15 th & Survived \\
\hline 24 & $\begin{array}{l}\text { labour } \\
\text { Hypertension and small } \\
\text { antepartum } \\
\text { harmorrhages }\end{array}$ & 39 & Spontaneous & ND & 8 & 15 th & Survived \\
\hline 25 & Pre-eclamptic toxaemia & Probable term & Emergency caesarean & $($ scalp $)+$ & 4 & & Survived \\
\hline 26 & Small for dates & 39 & Assisted breech & ND & 7 & $<5$ th & Neonatal death, large \\
\hline 27 & $\begin{array}{l}\text { Hypertension and small } \\
\text { antepartum }\end{array}$ & 37 & $\begin{array}{l}\text { Emergency caesarean } \\
\text { section }\end{array}$ & $($ scalp $)+$ & 2 & $<5$ th & Survived \\
\hline 28 & $\begin{array}{l}\text { haemorrhages } \\
\text { Severe pre-eclamptic }\end{array}$ & 37 & Spontaneous & & & 15 th & Intrauterine death \\
\hline 29 & $\begin{array}{l}\text { toxaemia } \\
\text { Hypertension }\end{array}$ & 39 & $\begin{array}{c}\text { Emergency caesarean } \\
\text { section }\end{array}$ & $\begin{array}{l}\text { Cord } \\
\text { presentation }\end{array}$ & 9 & 30th & Survived \\
\hline 30 & Rheumatic heart disease & 32 & Forceps & & & & $\begin{array}{l}\text { Intrauterine death } \\
\text { (multiple abnormalities) }\end{array}$ \\
\hline 31 & $\begin{array}{l}\text { Severe pre-eclamptic } \\
\text { toxaemia }\end{array}$ & 33 & $\begin{array}{l}\text { "Emergency" caesarian } \\
\text { section" }\end{array}$ & + (UA and UV) & 2 & 7th & Survived \\
\hline 32 & $\begin{array}{l}\text { Moderate pre-eclamptic } \\
\text { toxaemia }\end{array}$ & 37 & $\begin{array}{l}\text { Emergency caesarean } \\
\text { section }\end{array}$ & $\begin{array}{l}+(\text { scalp, UA, } \\
\text { and UV) }\end{array}$ & 1 & $<5$ th & Survived \\
\hline \multicolumn{8}{|c|}{ Group 4 (low oestrogen values; few movements) } \\
\hline $\begin{array}{l}33 \\
34 \\
35 \\
36\end{array}$ & $\begin{array}{l}\text { Severe hypertension } \\
\text { Severe hypertension } \\
\text { Severe Rh isoimmunisation } \\
\text { Severe pre-eclamptic } \\
\text { toxaemia }\end{array}$ & $\begin{array}{l}31 \\
33 \\
32 \\
32\end{array}$ & $\begin{array}{l}\text { Spontaneous } \\
\text { Spontaneous } \\
\text { Spontaneous } \\
\text { Emergency caesarean } \\
\text { section }\end{array}$ & $+(\mathbf{U A})$ & 3 & $\begin{array}{r}10 \text { th } \\
<5 \text { th } \\
\text { Invalid } \\
<5 \text { th }\end{array}$ & $\begin{array}{l}\text { Intrauterine death } \\
\text { Intrauterine death } \\
\text { Intrauterine death } \\
\text { Neonatal death } \\
\quad \text { (respiratory distress) }\end{array}$ \\
\hline
\end{tabular}




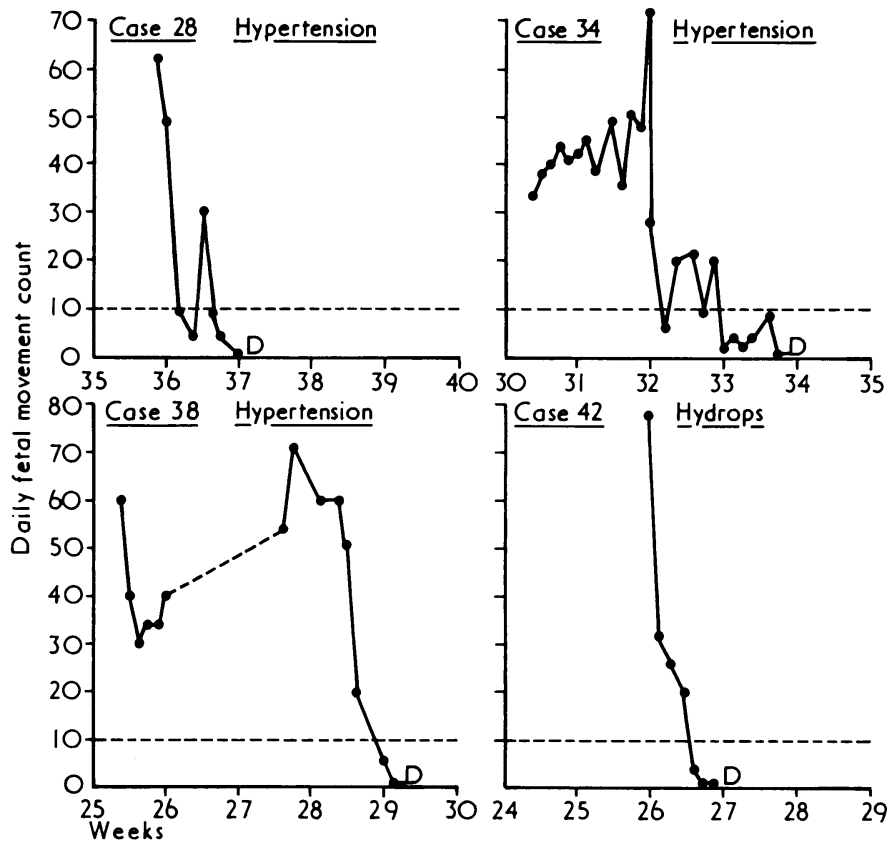

FIG 3-DFMCs of four patients whose infants died in utero before labour. Time of death is indicated (D). (See also tables II and III.)

\section{Discussion}

In normal pregnancies about $2.5 \%$ of DFMCs fell below 10 movements $/ 12$ hours. Intrauterine death was preceded by a rapid diminution of fetal movements, usually over three or four days, followed by cessation for 12 to 48 hours before death occurred. This latter observation corresponds to the "movement alarm signal" described by Sadovsky et al. ${ }^{6}$

Normal oestrogen values when combined with a normal DFMC were associated with good fetal outcome in a population at risk. On the other hand, a low DFMC was associated with a
TABLE III-Details of antepartum fetal deaths among inpatients not included in groups 2 and 3

\begin{tabular}{|c|c|c|c|c|c|}
\hline $\begin{array}{l}\text { Case } \\
\text { No }\end{array}$ & Pregnancy complication & $\begin{array}{c}\text { Maturity } \\
\text { (completed } \\
\text { weeks) }\end{array}$ & $\begin{array}{c}\text { Percentile } \\
\text { weight }\end{array}$ & $\begin{array}{l}\text { Oestrogen } \\
\text { excretion }\end{array}$ & DFMC \\
\hline 37 & Pre-eclamptic toxaemia & 31 & $<5$ th & Low & \\
\hline $\begin{array}{l}38 \\
39\end{array}$ & $\begin{array}{l}\text { Severe hypertension } \\
\text { Mild hypertension, } \\
\text { patient educationally } \\
\text { subnormal }\end{array}$ & $\begin{array}{l}29 \\
39\end{array}$ & $\begin{array}{l}800 \mathrm{~g} \\
20 \text { th }\end{array}$ & & Low \\
\hline 40 & $\begin{array}{l}\text { Severe } \mathrm{Rh} \\
\text { isoimmunisation }\end{array}$ & 30 & Invalid & & \\
\hline $\begin{array}{l}41 \\
42\end{array}$ & $\begin{array}{l}\text { Acute polyhydramnios } \\
\text { Severe } R \text { h } \\
\text { isoimmunisation }\end{array}$ & $\begin{array}{l}31 \\
27\end{array}$ & $\begin{array}{l}\text { 40th } \\
\text { Invalid }\end{array}$ & & Low \\
\hline 43 & $\begin{array}{l}\text { Diabetes, pre-eclamptic } \\
\text { toxaemia, abruptio } \\
\text { placentae }\end{array}$ & 28 & $660 \mathrm{~g}$ & & Low \\
\hline
\end{tabular}

high incidence of fetal asphyxia and intrauterine death even when urinary oestrogen levels were normal.

We believe that the DFMC is useful in the more accurate prediction of imminent fetal death. Of greater clinical importance is the observation that a normal fetal movement count was generally associated with a good outcome. The finding of a normal DFMC would thus reassure the obstetrician who wishes to defer delivery to gain further fetal maturity.

We thank Professor B M Hibbard for his helpful criticism and the nursing staff for their co-operation. We are grateful to $\mathrm{Mr} R$ Newcombe, department of medical statistics, University Hospital of Wales, for his statistical help.

\section{References}

1 Sadovsky, E, and Yaffe, H, Obstetrics and Gynecology, 1973, 41, 845.

2 Mathews, D D, Lancet, 1973, 1, 1315.

${ }^{3}$ Reinold, E, Fournal of Perinatal Medicine, 1973, 1, 65.

4 Sadovsky, E, et al, Lancet, 1973, 1, 1141.

5 Thomson, A M, Billewicz, W Z, and Hytten, F E, fournal of Obstetrics and Gynaecology of the British Commonwealth, 1968, 75, 903.

6 Sadovsky, E, Yaffe, H, and Polishuk, W Z, International fournal of Gynaecology and Obstetrics, 1974, 12, 75.

\title{
Immunological studies in pre-eclamptic toxaemia
}

\author{
N C THOMSON, R D STEVENSON, WILHELMINA M BEHAN, DIANE P SLOAN, C H W HORNE
}

British Medical fournal, 1976, 1, 1307-1309

\section{Summary}

Although five patients with severe pre-eclamptic toxaemia (PET) had increased anticomplementary activity in their serum, there was no evidence of complement activation in the plasma of four of the five patients. These results suggest that circulating immune complexes are not implicated in the pathogenesis of PET. No

Departments of Medicine and Pathology, Western Infirmary, Glasgow G11 6NT

N C THOMSON, MB, MRCP, medical registrar

$R$ D STEVENSON, $M B$, MRCP, lecturer in medicine

WILHELMINA M BEHAN, MB, MRCPATH, lecturer in pathology

DIANE J P SLOAN, BSC, technician

Department of Pathology, University Medical Building, Aberdeen AB9 2ZD

C H W HORNE, MD, MRCPATH, senior lecturer in pathology significant correlation was found between anticomplementary activity and pregnancy-associated $\alpha_{2}$-glycoprotein.

\section{Introduction}

It is now established that in normal pregnancy there is a maternal immune response to trophoblastic antigens that involves both cell-mediated and humoral factors. ${ }^{1-3}$ In preeclamptic toxaemia (PET) an immunological disturbance is suggested by studies showing a correlation between the incidence of the disease and the degree of maternal/fetal histoincompatibility. ${ }^{4}$ Immunoglobulin and complement have also been detected in the renal glomeruli of pre-eclamptic patients immediately after delivery. ${ }^{56}$

Maternal antibody production to paternal transplantation antigens in a first pregnancy could be considered analogous to primary immunisation, whereas subsequent pregnancies would elicit a form of secondary immune response in which the antibody titre would be higher than in the first pregnancy. Part of the function of such antibodies might be to neutralise soluble 